\title{
Syngas Characteristics from UCG Gasification Process with Lignite and Subbituminous Coal Types
}

\author{
Sarmidi $^{1}$, M. Yerizam ${ }^{2}$, Aida Syarif ${ }^{3}$ \\ ${ }^{1,3}$ Renewable Energy Engineering Department, Politeknik Negeri Sriwijaya, Indonesia \\ ${ }^{1}$ Department of Mining Equipment Operation, Bukit Asam Mining Industry Community College (BA-MICC), Indonesia \\ ${ }^{2}$ Chemical Engineering Department, Politeknik Negeri Sriwijaya, Palembang, Indonesia
}

\begin{tabular}{l} 
Article Info \\
\hline Article history: \\
Received July 11, 2021 \\
Revised August 10, 2021 \\
Accepted August 20, 2021 \\
\hline
\end{tabular}

\section{Keywords:}

Coal

UCG

Gasification

Lignite

Subbituminuos

\begin{abstract}
Underground Coal Gasification (UCG) is the process of converting the materials used to make synthetic gas in a feasible and economically attractive manner as a method for harnessing energy from underground coal sources. Coal gasification will produce a gas producer in the form of synthetic gas (syngas) with the main components consisting of carbon monoxide (CO), hydrogen $\left(\mathrm{H}_{2}\right)$, carbon dioxide $\left(\mathrm{CO}_{2}\right)$ and nitrogen $\left(\mathrm{N}_{2}\right)$ and low pollutants. The highest temperature produced with MT 47 lignite coal using an oxygen velocity of 5 liters/minute was $240^{\circ} \mathrm{C}$ at the 35th minute, while the lowest temperature was $95^{\circ} \mathrm{C}$ at the 95 th minute. For Subbituminous AL 51 coal using an oxygen velocity of 5 liters/minute, the highest temperature is $354^{\circ} \mathrm{C}$ at 75 minutes, while the lowest temperature is $106^{\circ} \mathrm{C}$ at 130 minutes. At an oxygen velocity of 5 liters/minute the flash point / burn test is on the MT 47 lignite coal type in the 10th minute and at a temperature of $170^{\circ} \mathrm{C}$. Meanwhile, the AL 51 subbituminous coal type is in the 30th minute and at a temperature of $313^{\circ} \mathrm{C}$. Based on the discussion and analysis of data from the gasification test of lignite and subbituminous coal with variations in oxygen velocity of 5 liters/minute, the results obtained are that lignite coal burns faster (burn test) in the 10th minute at a temperature of $170^{\circ} \mathrm{C}$, in the subbituminous type it has higher temperature $313^{\circ} \mathrm{C}$ and longer burn test at 30 minutes.
\end{abstract}

This is an open access article under the CC BY-SA license.

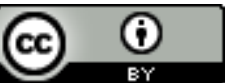

\section{Corresponding Author:}

M. Yerizam,

Chemical Engineering Department

Politeknik Negeri Sriwijaya, Palembang, Indonesia.

Email: yerizam@polsri.ac.id

\section{INTRODUCTION}

Indonesia as a country has various types of energy resources which are quite abundant [1]. Electrical energy is one of the basic needs of people everywhere. Both in developing countries such as Indonesia, as well as developed countries. The increasing demand for electrical energy in Indonesia is currently not balanced with the availability of electrical energy supply or the electrical energy crisis is something that cannot be avoided. [2]. The need for electrical energy in the world from year to year is increasing along with the development of human civilization. Meanwhile, the supply of electrical energy sourced from oil, natural gas, and coal has several limitations, including non-renewability, pollution, and environmental damage produced by these three energy sources in the short and long term. The increase in energy consumption in Indonesia encourages energy conservation in the field of renewable energy [3]. Renewable energy is nonfossil energy that can be renewed and managed properly. The limitations of fossil energy require 
diversification of energy sources to ensure the availability of sustainable energy leading to the intensification of renewable energy [4]. Therefore, sustainable renewable energy resources that can be classified as renewable energy are geothermal, hydro, solar, wind, biomass, marine, fuel cells, and nuclear [5]. On the other hand, electrical energy from renewable sources, such as solar, geothermal, wind, biomass, ocean currents, and waves has not been fully utilized. Indonesia has abundant new renewable energy potential, consisting of geothermal, hydro energy, wind energy, bioenergy (bioethanol, biodiesel, biomass), ocean current energy, nuclear energy, and solar energy which can be applied or utilized in almost every region in Indonesia. Indonesian [6].

Public awareness to pay more attention to the potential for new and renewable energy is needed in order to utilize the potentials of new and renewable energy from a small scale so that awareness will be fostered to protect the environment and contribute to sustainable development, and can support national energy security. Coal is the most rapidly growing energy source in the world in recent years - faster than gas, oil, nuclear, hydro and renewable energy, [7]. Utilization of coal energy sources is also increasing along with the decline in oil production. Coal is the most important energy source, widely used for electricity generation, and also serves as a basic energy source for the metal smelting, cement and other industries (metallurgy, textiles, pulp paper) [8]. Indonesia has a large potential for coal resources. Coal has the highest carbon content and impurities (sulfur, nitrogen and others). Coal releases gases $\left(\mathrm{CO}_{2}, \mathrm{~N}_{2} \mathrm{O}, \mathrm{NOx}, \mathrm{SOx}\right.$ and $\mathrm{Hg}$ ) that cause global warming and pollution. Coal deposits in mines can also cause wastewater that has a high acidity level and has a high potential for pollution to the surrounding environment [9], but this can be solved by the electrocoagulation method [10]. Therefore, the use of clean and efficient coal is still a challenge that needs to be extensively pursued in order to extend the life of its availability. In addition to minimizing the global environmental burden, one way to increase the utilization of clean coal is through the coal gasification process. Gasification technology is a process of burning solid raw materials involving the reaction between oxygen, water vapor and carbon dioxide. The combustion products are reduced to flammable gases, such as carbon monoxide $(\mathrm{CO})$, hydrogen $\left(\mathrm{H}_{2}\right)$ and methane $\left(\mathrm{CH}_{4}\right)$ [11].

Coal gasification will produce producer gas in the form of synthetic gas (syngas) with the main components consisting of carbon monoxide $(\mathrm{CO})$, hydrogen $\left(\mathrm{H}_{2}\right)$, carbon dioxide $\left(\mathrm{CO}_{2}\right)$ and nitrogen $\left(\mathrm{N}_{2}\right)$ and low pollutants. So that energy experts have focused on developing coal gasification to meet future energy consumption. Coal suitable for UCG development is lignite to bituminous [12]. The deeper the coal seam, the higher the cost and risk of production if done using conventional methods, this gasification process is one method that can add to the economic value of coal [13]. Underground Coal Gasification (UCG) is a new technology that utilizes unmined coal, [14]. Some of the gas from the gasification can be used as fuel for power generation stations and some can be used as synthetic materials (syngas) for chemicals, such as hydrogen, methanol or other gaseous chemicals. UCG has advantages because it produces gas fuel that is more environmentally friendly in addition to utilizing subsurface coal which is currently uneconomical to mine. The development of this coal prototype is carried out to develop an underground coal gasification system, to produce the best quality syngas, and it is hoped that this UCG prototype will become a reference in future studies to increase coal syngas production.

\section{RESEARCH METHOD}

\subsection{MATERIAL}

Coal is a solid hydrocarbon fuel formed from plants in an oxygen-free environment which is influenced by long-lasting heat and pressure in nature with a complex composition [15]. In the industrial world associated with the combustion process and coal smelting, the main problem is to evaluate the properties of coal before using it. Until now in many power plants, chemical analysis methods used to obtain information about all parameters (proximate analysis, ultimate analysis, and calorific value) are very time consuming and require a lot of technical skills with detailed knowledge of coal chemistry testing [16]. In general, coal can be categorized based on water content, carbon content and calorific value as shown in Table $1[17]$.

Table 1. Coal Category

\begin{tabular}{cllc}
\hline Category & $\mathrm{H}_{2} \mathrm{O}(\%)$ & $\mathrm{C}(\%)$ & Calorific $(\mathrm{Kcal} / \mathrm{kg})$ \\
\hline Lignite & 43,4 & 37,8 & 4113 \\
Subbituminous & 23,4 & 42,4 & 5403 \\
Bituminous & 11,6 & 54,2 & 7159 \\
Anthracite & 3,2 & 95,6 & 8027 \\
\hline
\end{tabular}




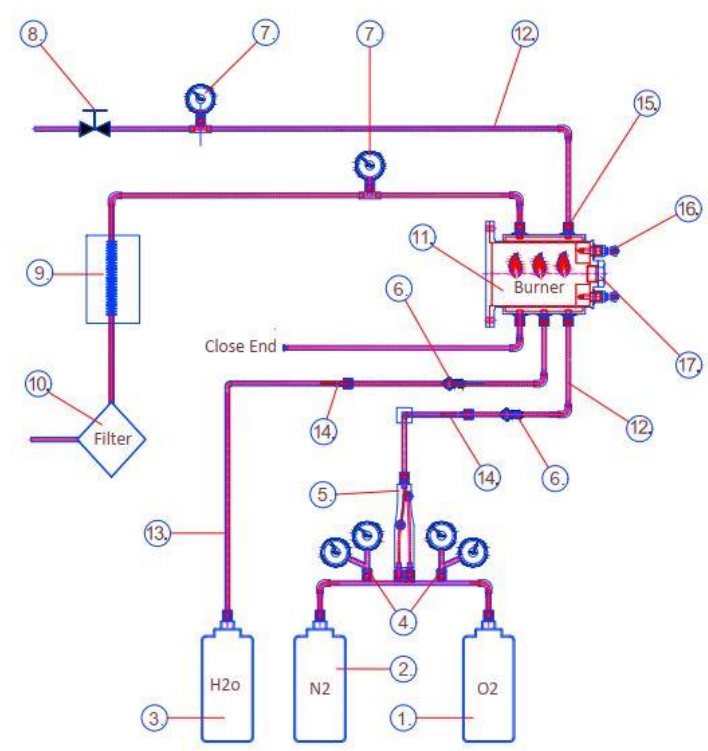

Figure 1. Underground Coal Gasification Prototype Design Schematic

Table 2 Description of UCG Prototype Components

\begin{tabular}{clcclc}
\hline No & Name Component & Qty & No & Keterangan & Qty \\
\hline 1 & Oxygen Cylinder & 1 Set & 10 & Filters & 1 Set \\
2 & Nitrogen Tubes & 1 Set & 11 & Combution & 1 Set \\
3 & Tubes Air and Steam & 1 Set & 12 & Tube & 20 Meters \\
4 & Regulators & 2 Pcs & 13 & Hose & 20 Meters \\
5 & Gun Mixers & 1 Set & 14 & Conector Hose & 2 Pcs \\
6 & Check Valve & 2 Pcs & 15 & Conector Tube & 2 Pcs \\
7 & Pressure Gauge & 2 Pcs & 16 & Glow Plug & 4 Pcs \\
8 & Gate Valve & 2 Pcs & 17 & Plugs & 1 Pcs \\
9 & Coolers & 1 Set & & & \\
\hline
\end{tabular}

Underground coal gasification is the process of in-situ coal gasification in coal seams deep underground by injection of compressed air through bore wells and producing coal fuel gas through production wells [18]. The UCG process involves the reaction of oxygen, air or steam with coal carbon and other pyrolysis products to produce syngas consisting mainly of methane, hydrogen, carbon monoxide, carbon dioxide and steam [19]. For example, hydrogen is a clean fuel that con stitutes a valuable chemical feedstock for different chemical processes and synthesis [20]. The resulting methane-rich syngas is compatible with natural gas and can be used as synthetic natural gas (SNG) for power generation, industrial feedstock or conversion to other fuels and chemicals [21]. In general, as a fuel, methane has high economic value as well as environmental, energy security and industrial safety benefits [22].

Underground coal gasification converts coal to gas while it is still in the coal seam (in-situ). Gas is produced and extracted through wells drilled into the coal seam. The well, in this case the injection, is used to supply oxidants (air, oxygen and nitrogen) and steam to ignite and refuel the underground combustion process. Separate production wells are used to bring product gas to the surface. High-pressure combustion is carried out at $700-900^{\circ} \mathrm{C}\left(1,290-1,650^{\circ} \mathrm{F}\right)$, but can reach up to $1,500^{\circ} \mathrm{C}\left(2,730^{\circ} \mathrm{F}\right)$. The process decomposes coal and produces carbon dioxide $\left(\mathrm{CO}_{2}\right)$, hydrogen $\left(\mathrm{H}_{2}\right)$, carbon monoxide $(\mathrm{CO})$ and methane $\left(\mathrm{CH}_{4}\right)$. In addition, small amounts of contaminants including sulfur oxide (SOx), mono-nitrogen oxide (NOx), and hydrogen sulfide $\left(\mathrm{H}_{2} \mathrm{~S}\right)$ are produced. It is necessary to monitor the temperature in the combustion chamber system to maintain stability [23]. Syngas production through gasification of low quality coal, which in Indonesia reaches 70\% [24]-[27] will be able to increase the selling price of the coal.

Syngas from coal gasification has good prospects for three reasons, first, syngas products are very commercial, widely used by industries, both for chemicals, energy, and transportation fuels. Second, syngas is more environmentally friendly than natural gas or petroleum with low $\mathrm{CO}_{2}, \mathrm{SOx}$, and $\mathrm{NOx}$ emissions. Third, the abundance of coal resources in Indonesia. In addition to its large reserves, coal gasification can 
also utilize lignite coal, which in Indonesia reaches 70\% [24]. So that the coal gasification process will produce synthetic gas (syngas) with the main components consisting of carbon monoxide (CO), hydrogen $\left(\mathrm{H}_{2}\right)$, and $\left(\mathrm{CH}_{4}\right)$ [25]. Different amounts of hydrocarbons in the syngas, at different exit temperatures, use different ratios of steam and oxygen to coal feed [26][30]. In this case, in the syngas content the amount of hydrocarbons will be different, the temperature that comes out will be different too and this is influenced by the feed or oxygen that is flowed into the combustion chamber or combustion.

\section{RESULTS AND DISCUSSION}

Each type of coal has a different composition. Proxymite coal content testing is needed to determine the character and composition of the coal, physically, chemically and fuel properties of the coal that will be used in the gasification process. Proxymite analysis of coal type MT 47 and AL 51 which shows the content of moister, folate mater, ash and fixcarbon in the coal. This sampling was carried out in the laboratory of the Coal Transport Handling work unit of PT. Bukit Asam.

Table 3. Coal Proximite Analysis MT 47 and AL 51

\begin{tabular}{ccc}
\hline Proximate Analysis & MT 47 & AL 51 \\
\hline Seam & A1 & A1 \\
Kalori $(\mathrm{kcal} / \mathrm{kg}$, ar $)$ & 4700 & 5300 \\
Moisture $(\%$, abd) & 14.68 & 10.35 \\
Ash Content $(\%$, abd $)$ & 5.3 & 17.02 \\
Volatile Matter $(\%$, abd $)$ & 40.58 & 35.58 \\
Fixed Carbon $(\%$, abd $)$ & 39.45 & 37.05 \\
\hline
\end{tabular}

The ultimate test of coal content is needed to determine the character and composition of the coal, physically, chemically and fuel properties of the coal that will be used in the gasification process. The ultimate analysis of the MT 47 and AL 51 coal types which shows the content of Carbon, Hydrogen, Sulfur, Nitrogen and Oxygen in the coal. This sampling was carried out in the laboratory of the Coal Transport Handling work unit of PT. Bukit Asam.

Table 4. Coal Ultimate Analysis MT 47 and AL 51

\begin{tabular}{ccc}
\hline Ultimate Analysis & MT 47 & AL 51 \\
\hline Seam & A1 & A1 \\
Kalori $(\mathrm{kcal} / \mathrm{kg}$, ar) & 4700 & 5300 \\
Carbon $(\%$, abd) & 60.66 & 54.71 \\
Hydrogen $(\%$, abd) & 4.39 & 5.27 \\
Nitrogen $(\%$, abd) & 0.69 & 0.81 \\
Sulfur $(\%$, abd) & 1.03 & 0.68 \\
Oxygen $(\%$, abd) & 13.26 & 21.54 \\
\hline
\end{tabular}

Figure 2 explains that the highest temperature produced with MT 47 lignite coal uses an oxygen velocity of 5 liters/minute.

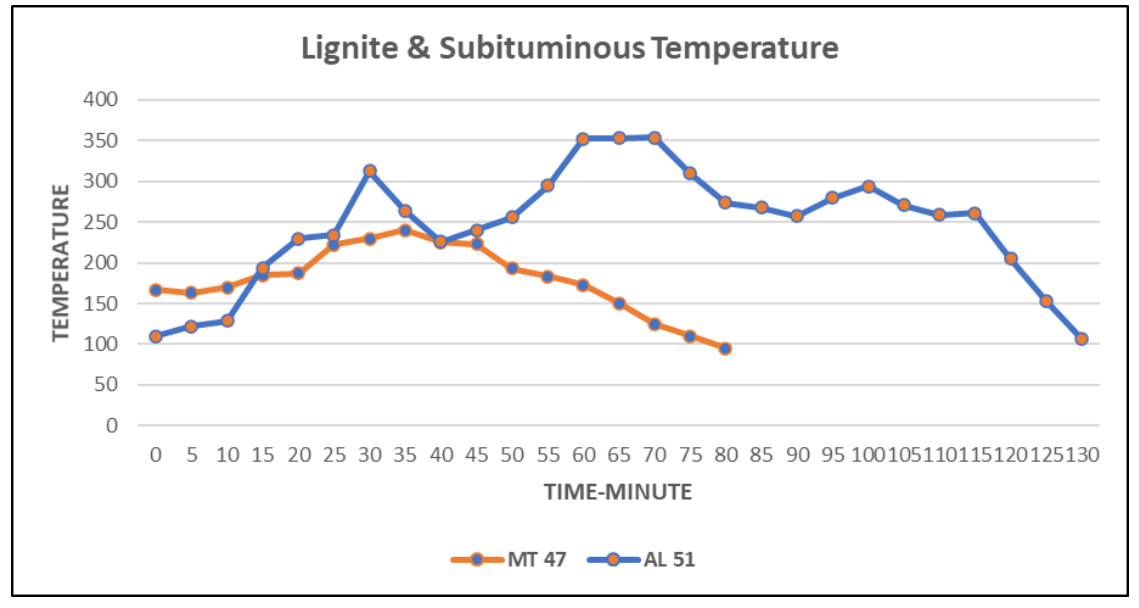

Figure 2. Temperature with oxygen speed 5 Liter/Minute 
Figure 2 explains that, the highest temperature produced with MT 47 lignite coal using an oxygen velocity of 5 liters/minute is $240^{\circ} \mathrm{C}$ at the 35 th minute, while the lowest temperature is $95^{\circ} \mathrm{C}$ at the 80 th minute. For Subbituminous AL 51 coal using an oxygen velocity of 5 liters/minute, the highest temperature is $354^{\circ} \mathrm{C}$ at 70 minutes, while the lowest temperature is $106^{\circ} \mathrm{C}$ at 130 minutes.

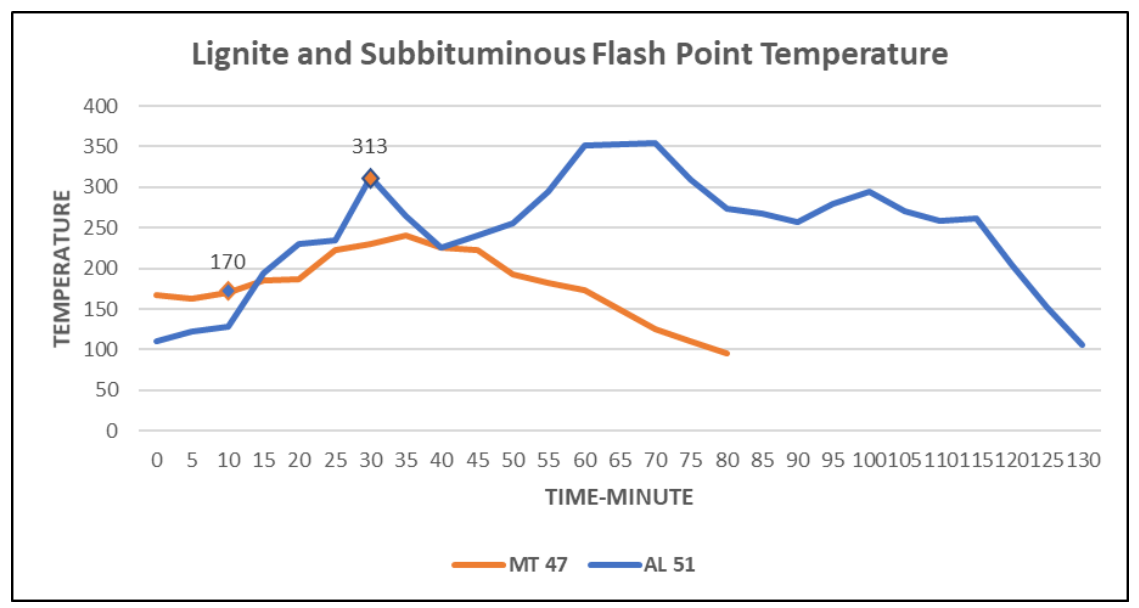

Figure 3. Flash point test / burn test.

Figure 3 explains that, at an oxygen velocity of 5 liters/minute, the flash point / burn test is for lignite coal type MT 47 in the 10th minute and at a temperature of $170^{\circ} \mathrm{C}$. Meanwhile, for the subbituminous coal type AL 51 in the 30th minute and at a temperature of $313^{\circ} \mathrm{C}$. This means that by using lignite coal, it burns faster (burning test) but the subbituminous type has a higher temperature.

\section{CONCLUSION}

Based on the discussion and analysis of data from gasification tests for lignite and subbituminous coal with variations in oxygen velocity of 5 liters/minute, it can be concluded that the type of lignite coal burns faster (burn test) in the 20th minute at a temperature of $318.5^{\circ} \mathrm{C}$. Subbituminous has a higher temperature of $460^{\circ} \mathrm{C}$ and a longer burn test at 30 minutes.

\section{ACKNOWLEDGEMENTS}

The authors would like to thank the Bukit Asam Foundation, the Head of the Study Program, the Head of the Chemical Laboratory and the staff of the Sriwijaya State Polytechnic, the General Manager of UPTE and the Senior Managers and Managers of PT. Bukit Asam for supporting research and analysis.

\section{REFERENCES}

[1] Dafi Dzulfikar, Wisnu Broto, "Optimalisasi Pemanfaatan Energi Listrik Tenaga Surya Skala Rumah Tangga," Vol 5 (2016): PROSIDING SEMINAR NASIONAL FISIKA (E-JOURNAL) SNF2016.

[2] Achmad Imam Agung, Potensi Sumber Energi Alternatif Dalam Mendukung Kelistrikan Nasional, “ Jurnal Pendidikan Teknik Elektro, Volume 2 Nomer 2 Tahun 2013, 892-897.

[3] Rusdianasari, Y Bow and R A N Moulita, "Temperature effect on the biodiesel quality from waste cooking oil by induction heating," IOP Publishing. Journal of Physics: Conference Series iCAST-ES 2019. 1450 (2020) 012003.

[4] Reinhard Ploetz, Rusdiana and Eviliana, RENEWABLE ENERGY: ADVANTAGES AND DISADVANTAGES, Proceeding Forum in Research, Science, and Technology (FIRST) 2016

[5] Abubakar Lubis, 'Energi Terbarukan Dalam Pembangunan Berkelanjutan,' Vol. 8 No. 2 (2007): JURNAL TEKNOLOGI LINGKUNGAN.

[6] Rosyid Ridlo Al Hakim, "Model Energi Indonesia, Tinjauan Potensi Energy Terbarukan Untuk Ketahanan Energi Di Indonesia: Literatur Review." ANDASIH Jurnal Pengabdian kepada Masyarakat ISSN: - Vol. 1, No. 1, April 2020.

[7] Aida Syarif, M. Said, A. Halim PKS, Endang Wiwik and DH., "Characerization of Geochemical Waste Rock on Indicate and Mitigation Acid Mine Drainage at Coal Mining Bukit Asam Tanjung Enim". Proceedings of The 5th Sriwijaya International Seminar on Energy and Environmental Science \& Technology Palembang, Indonesia September 10-11, 2014. 
[8] Gunara, M, "Potensi Batubara Sebagai Sumber Energi Alternatif Untuk Pengembangan Industri Logam”. Prosiding Seminar Nasional Teknoka, 2, M22 - M27, 2017.

[9] Rusdianasari, S Arita, E Ibrahim and Ngudiantoro, "Reduction of Metal Contents in Coal Stockpile Wastewater using Electrocoagulation”, Applied Mechanics and Materials Vol. 391, pp 29-33, 2013.

[10] Rusdianasari, Y Bow and A Taqwa, "Treatment of Coal Stockpile Wastewater by Electrocoagulation Using Aluminum Electrodes", Advanced Materials Research Vol. 896, pp 145-148, 2014.

[11] Setiawan, Budi (2014) Studi Gasifikasi Batu Bara Lignite Dengan Variasi Kecepatan Udara Untuk Keperluan Karbonasi. Skripsi thesis, Universitas Muhammadiyah Surakarta.

[12] Asep B. Purnama, Yudha S. Subarna, Yoga A. Sendjadja, Budi Muljana Dan Binarko Santoso., "Potensi Batubara Untuk Pengembangan Gasifikasi Bawah Permukaan : Studi Kasus Desa Macang Sakti, Provinsi Sumatera Selatan, “Jurnal Teknologi Mineral dan Batubara Volume 13, Nomor 1, Januari $2017: 13-30$

[13] Deri Rafsanjani, Marsel Akbar, M Tressna Gandapradana., "Potensi Gasifikasi Batubara Bawah Tanah Daerah Muara Tiga Besar, PT.Bukit Asam Tbk. Kabupaten Lahat, Sumatera Selatan, " Prosiding Seminar Nasional Teknik Lingkungan Kebumian Ke-II "Strategi Pengelolaan Lingkungan Sumberdaya Mineral dan Energi Untuk Pembangunan Berkelanjutan" Jurusan Teknik Lingkungan, Fakultas Teknologi Mineral, UPN Veteran Yogyakarta, 7 November 2020

[14] Mesut Gur and Engin Deniz Canbaz., "Analysis of syngas production and reaction zones in hydrogen oriented underground coal gasification," Fuel 269 (2020) 117331, 0016-2361/ (C) 2020 Published by Elsevier Ltd.

[15] Arif Ismul Hadi, Refrizon, dan Erlena Susanti., 2012. Analisis Kualitas Batu Bara Berdasarkan Nilai HGI dengan Standar ASTM. Bengkulu : Universitas Bengkulu.

[16] D.M. Kate, N.K. Choudhari, A.R. Chaudhari., 2013. Evaluation of Properties of Coal Using Various NDT Methods. India : Smt. Bhagwati Chaturvedi College of Engineering.

[17] Considine, D. M., 1974. Chemical and Process Technology Encyclopedia. New York : Mc Graw-Hill Pub.

[18] Irfan Naufal Fauzi, Zulfahmi Zulfahmi.,"Analisis Dan Pemodelan Distribusi Tegangan Sumur Bor Injeksi Pada Proses Underground Coal Gasification," Jurnal Teknologi Mineral dan Batubara Volume 17, Nomor 1, Januari 2021: 1 - 12.

[19] Sunggyu Lee, James G. Speight, Sudarshan K. Loyalka.,Handbook teknologi bahan bakar alternatif. 2014: CRC Tekan DOI: https://doi.org/10.1201/b17157.

[20] K. Stanczyk, N. Howanies, A. Smolinski, J. Swiaadrowski, K. Kapusta, et al, "Gasification of Lignite and Hard Coal and Oxygen Enriched Air in a Pilot Scale Ex-Situ Reactor for Underground Gasification". Published by Elsevier, 0016-2361, 1953-1962, 2011.

[21] Wang B, Yang E, G Hao J., Kemajuan dalam proses konversi metana. Catal Hari ini 2017; 285: 147-58.https://doi.org/10.1016/j.cattod.2017.01.023.

[22] Badan Energi Internasional (IEA) Energi Sektor Metana Pemulihan dan Penggunaan: The Pentingnya Kebijakan; 2009.

[23] Muhammad Yerizam, Suri Andayana and Utari Oktavia., "Effect of Temperature and Starter Concentration on the Fermentation Process in Making MOCAF," IOP Publishing, Journal of Physics: Conference Series. FIRST 2019. 1500 (2020) 012050.

[24] "Handbook of Energy \& Economic Statistics of Indonesia", Pusat Data dan Informasi Kementrian Energi dan Sumber Daya Mineral Indonesia (2013).

[25] Muslim Efendi Harahap, Endro Wahju Tjahjono., Technology Review Process Of Synthetic Gas From Coal Utilization And Prospect In Downstream Industries. Vol. 10 No. 1 (2016): Majalah Ilmiah Pengkajian Industri

[26] Lawrence K. Rath, James R. Longanbach., A Perspective On Syngas From Coal, Published online: 16 May 2007, https://www.tandfonline.com/doi/abs/10.1080/00908319108909001

[27] Rusdianasari, A. Syarif, M. Yerizam, M. S. Yusi, L. Kalsum, and Y. Bow, "Effect of Catalysts on the Quality of Biodiesel from Waste Cooking Oil by Induction Heating," J. Phys. Conf. Ser., vol. 1500, no. 1, 2020, doi: 10.1088/1742-6596/1500/1/012052.

[28] Y. Bow, L. Kalsum, A. Hasan, A. Husaini and Rusdianasari, "The Purification of Biogas with Monoethanolamine (MEA) Solution Based on Biogas Flow Rate,"Proceedings of the 4th Forum in Research, Science, and Technology (FIRST-T1-T2-2020), vol. 7, pp. 12-17, 2021.

[29] Y. Bow, A. Syakdani, M. Taufik, and Rusdianasari, "Effect of Drying Ariflow Rate on $\mathrm{H}_{2} \mathrm{O}$ Mass Evaporated on Banana Chips Drying using Photovoltaic Solar Panel", J. Phys.: Conf. Ser. 1500 012015, 2020. 
[30] Rusdianasari, S. Arita, E. Ibrahim, and Ngudiantoro, "Characteristic of Coal Stocpile in Lowland and the effect to Environment", Springer Series in Materials Science, Volume 204 in Recent Trends in Physics of material Science and Technology, 2015.

\section{BIOGRAPHIES OF AUTHORS}

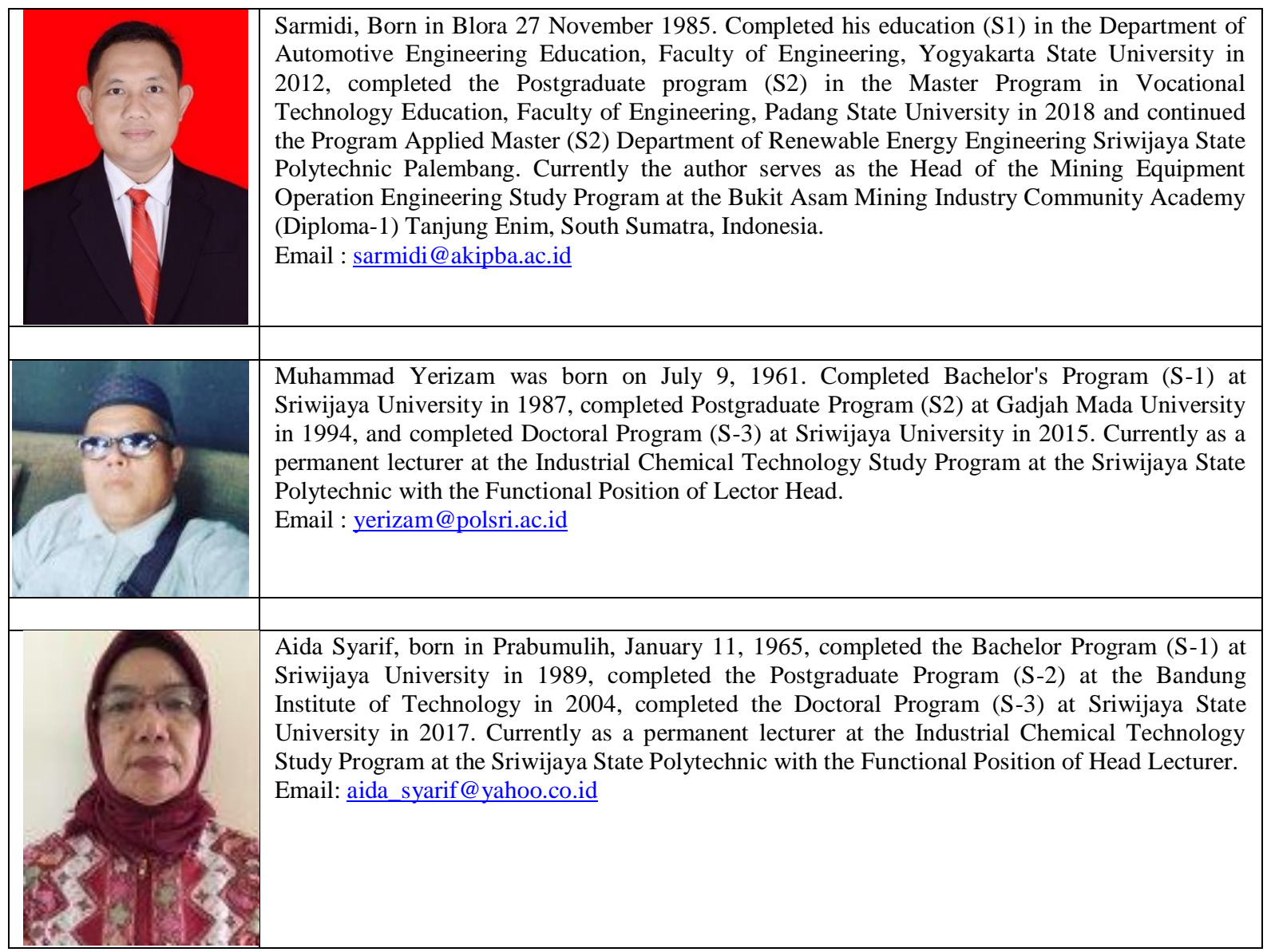

